\title{
GAME EDUKASI PADA PEMBELAJARAN MATEMATIKA: TANGGAPAN SISWA SMP BERDASARKAN GENDER
}

\author{
Nilza Humaira Salsabila ${ }^{1}$, Ulfa Lu'luilmaknun ${ }^{2}$, Dwi Novitasari ${ }^{3}$, Ratna Yulis Tyaningsih ${ }^{4}$, \\ Riska Ayu Ardani ${ }^{5}$ \\ 1,2,3,4 Pendidikan Matematika, Universitas Mataram \\ ${ }^{5}$ Pendidikan Matematika, UIN Walisongo Semarang \\ 1Email: nilza_hs@unram.ac.id
}

\begin{abstract}
The use of media in mathematics learning can help students to learn more easily. One of them is educational game media. The study aims to describe the responses of junior high school students based on gender to learn mathematics by using educational game media. The subjects of this study were $7^{\text {th }}$ and $8^{\text {th }}$ grade of junior high school students in Mataram-West Nusa Tenggara, a total of 101 students. Study data were obtained from a questionnaire about the use of educational games in mathematics classes. Study data processing using descriptive statistics, qualitative methods. The results of the study show that there are differences in responses between male and female students, towards: fun learning and increased motivation using media games and missions in educational games.
\end{abstract}

Keywords: Edukasi, Game, Gender, Mathematics

\begin{abstract}
Abstrak
Penggunaan media pada pembelajaran matematika dapat membantu siswa untuk lebih mudah belajar. Salah satunya media game edukasi. Adapun studi ini bertujuan untuk mendeskripsikan tanggapan siswa SMP berdasarkan gender terhadap pembelajaran matematika dengan menggunakan media game edukasi. Subjek penelitianini adalah siswaSMP kelas 7 dan 8 di Mataram-Nusa Tenggara Barat sebanyak 101 siswa. Data studi diperoleh dari kuesioner tentang penggunaan game edukasi di kelas matematika.Pengolahan data studi menggunakan statistic deskriptif ,metode kualitatif. Hasil studi menunjukkan bahwa terdapat perbedaan tanggapan antara siswa laki-laki dan perempuan, terkait: pembelajaran yang menyenangkan dan motivasi yang meningkatdenganmenggunakan media game, serta misi pada game edukasi.
\end{abstract}

Kata kunci: Education, Game, Gender, Matematika

Cara Menulis Sitasi: Salsabila, N.H., Lu'luilmaknun, U., Novitasari, D., Tyaningsih, R.Y, \& Ardani, R.A. (2020). Game edukasi pada pembelajaran matematika: tanggapan siswa SMP berdasarkan gender. Mathematic Education and Aplication Journal. Volume 2, No.1 halaman 25-32

Salah satu bentuk inovasi dalam dunia pendidikan matematika adalah mengintegrasikan berbagai media edukasi dengan perkembangan tekologi. Berbagai inovasi baru akan menunjang kesuksesan pembelajaran. Selain itu, pembelajaran yang efektif dan efisien dapat dihasilkan dengan memanfaatkan teknologi di dalam kelas matematika. Maka dari itu, penguasaan teknologi, informasi dan media merupakan salah satu tantangan yang dihadapi guru era sekarang (Pramuditya, Noto, \& Purwono, 2018: 166).

Penggunaan teknologi game di dalam pembelajaran matematika merupakan salah satu cara untuk belajar modern. Media game edukasi merupakan salah satu perangkat yang dapat digunakan dalam pembelajaran oleh guru untuk mencapai tujuan belajar. Gam eedukasi mengasosiasikan aspek 
pendidikan dan aspek hiburan. Media ini juga dapat digunakan dalam pembelajaran matematika di dalam maupun luar kelas. Siswa dapat belajar matematika sekaligus merasakan hiburan di dalam game.

Media game dapat memfasilitasi siswa laki-laki maupun perempuan untuk belajar matematika sambil bermain. Penelitian menunjukkan bahwa siswa laki-laki bermain game lebih sering dari siswa perempuan (Chan, 2008). Erfaniet al.(2010: 295) juga mengungkapkan bahwa jenis kelamin dan usia yang signifikan mempengaruhi kinerja pemain game. Lebih lanjut, hasil survey Pokkt dengan Decision Lab (2018) menunjukkan bahwa pengguna game mobile tidak hanya di kalangan laki-laki, tetapi game juga tidak kalah terkenal di kalangan perempuan. Data basis gamer di Indonesia menunjukkan bahwa terdapat $49 \%$ pengguna laki-laki dan 51\% pengguna perempuan. Ada tiga hal yang membuat pemain tertarik bermain game, khususnya Role Playing Game (RPG), yaitu: 1) rasa puas dan senang yang diperoleh saat bermain; 2) kualitas perangkat smartphone dan layanan internet; dan 3) teman bermain (Suartama, Suciptawati, \& Asih, 2019: 197).

Berbagai kelebihan dapat diperoleh melalui media game edukasi.Beberapa keunggulan dari media game edukasi secara umum adalah: 1) tampilan game yang lebih menarik dengan kombinasi berbagai warna; 2) game tidak membosankan karena diiringi dengan musik; 3) game praktis digunakan dimanapun karena tersedia di smartphone; dan 4) game dapat sebagai salah satu media belajar, sehingga belajar tidak hanya menggunakan buku (Abdullah \& Yunianta, 2018: 441; Setyadi. 2017: 92). Lebih lanjut, Wijaya (2009: 11) mengungkapkan bahwa bermain dalam pembelajaran matematika memiliki tiga manfaat, antara lain manfaat motivasi, manfaat sosial, dan manfaat konseptual.Penguasaan kemampuan kognitif dalam matematika dan kriteria karakter siswa juga dapat meningkat dengan media game (Pramesti dkk, 2014: 16).

Beberapa penelitian juga telah dilakukan terkait dengan penggunaan game matematika di Indonesia. Hasil penelitian tersebut memperlihatkan bahwa game mempunyai kapasitas sebagai sarana belajar matematika di Indonesia. Salah satunya, penelitian oleh Tassel, Novak, dan Wu (2018) menunjukkan bahwa perbedaan gender dalam kemampuan spasial dapat dikurangi dengan pelatihan spasial melalui bermaingame. Swalaganata (2018) juga mengembangkan media pembelajaran game aritmetika pada perangkat smartphone. Abdullah dan Yunianta (2018) menemukan bahwa media pembelajaran matematika berbasis game edukasi terbukti efektif pada materi trigonometri. Lebih lanjut, game edukasi berjenis RPG dan Puzzle juga berhasil meningkatkan hasil belajar siswa pada pembelajaran matematika (Hermawan, Herumurti, \& Kuswardayan, 2017).

Pemanfaatan teknologi dalam bidang pendidikan terus meningkat dari waktu ke waktu. Perlu dilakukan penelitian tentang hal tersebut, khususnya teknologi game sebagai media pembelajaran matematika. Berdasarkan latar belakang di atas, maka tujuan dari penelitian ini adalah untuk 
mendeskripsikan tanggapan siswa SMP berdasarkan gender terhadap penggunaan media pembelajaran game edukasi matematika.

\section{METODE}

Penelitian ini merupakan penelitian kuantitatif-kualitatif. Subjek pada studi ini berjumlah 101 siswasiswi, dengan 50 siswa laki-laki dan 51 perempuan. Instrumen pengumpulan data menggunakan kuesioner mengenai tanggapan siswa tentang media game edukasi pada pembelajaran matematika di dalam kelas. Adapun analisis data yang diperoleh menggunakan analisis statistic deskriptif dengan metode kualitatif, dimana data diolah menggunakan perangkat Microsoft Excel dan SPSS.

Kuesioner yang digunakan dalam studi initerdiri dari 5 pernyataan, dengan 4 skala likert yaitu: Sangat Setuju, Setuju, Tidak Setuju, dan Sangat Tidak Setuju. Berikut adalah contoh dari kuesioner yang digunakan dalam studi ini.

Tabel 1. Contoh Pernyataan pada Kuesioner Tanggapan Siswa SMP terhadap Media Game Edukasi

\begin{tabular}{|c|l|}
\hline No & \multicolumn{1}{|c|}{ Pernyataan } \\
\hline 1 & Belajarmenjadimenyenangkandengan media gameedukasi \\
\hline 2 & Media gameedukasimeningkatkanmotivasibelajarsiswa \\
\hline 3 & Misi yang disajikan media gameedukasimembuatsiswamemperhatikanmateri \\
\hline 4 & Menyelesaikanmisi pada media gameedukasimenantangsiswa \\
\hline
\end{tabular}

\section{HASIL DAN PEMBAHASAN}

Hasil dari data penelitiantersebutdapatdilihatdi bawah. Pembahasanberdasarkan data yang diperoleh juga disajikan.

\section{Belajar menjadi Menyenangkan dengan Media Game Edukasi}

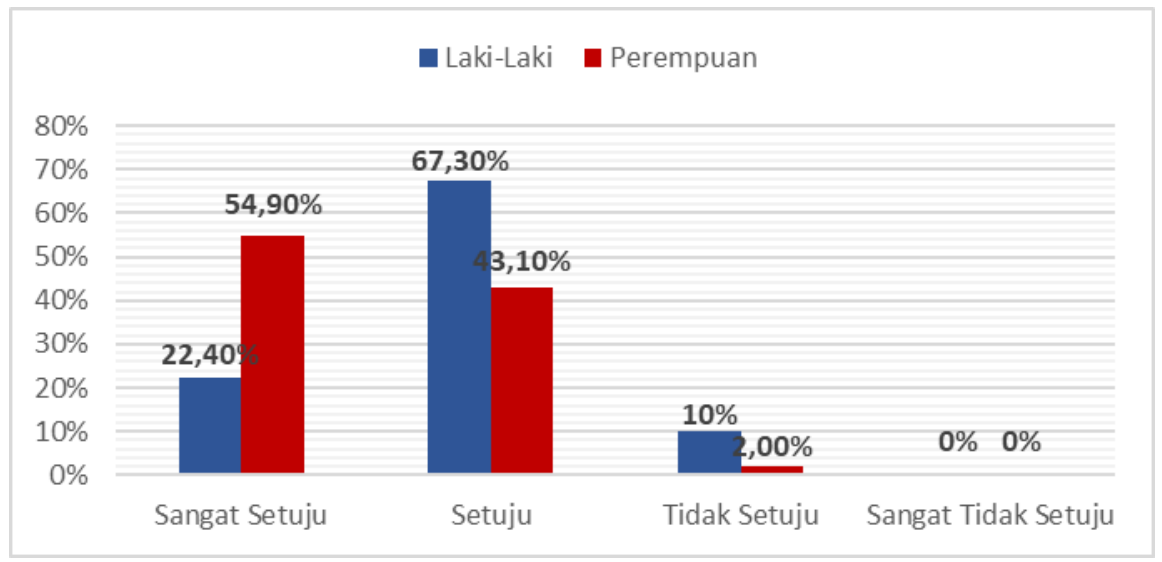

Gambar 1.TanggapanSiswa berdasarkan Gender pada Pernyataan 1 
Belajar menjadi menyenangkan karena siswa tidak hanya belajar untuk memperoleh pengetahuan baru melalui game, tetapi siswa juga bermain di dalam kelas. Ini merupakan belajar dengan cara yang baru, dimana mengintegrasikan teknologi dalam pembelajaran dengan game. Bermain menjadi proses belajar yang menyenangkan. Siswa dapat sekaligus merasakan hiburan ketika belajar. Hal ini mengurangi rasa tertekan dan stress siswa saat belajar maupun mengerjakan soal matematika.

Lebih lanjut, tidak hanya siswa laki-laki yang menganggap bahwa belajar dengan game menyenangkan, siswa perempuan juga menganggap demikian. Data ini menunjukkan bahwa game tidak hanya populer di kalangan lelaki saja. Arayaet al. (2011:2) dan Siregar (2017: 227) mengungkapkan bahwa game membuat belajar lebih menyenangkan, mudah, dan fleksibel.Tampilan game yang menarik yang diiringi juga dengan latar musik membuat belajar dengan game menjadi menyenangkan.

Data penelitian pada Gambar 1. juga menunjukkan bahwa lebih banyak siswa laki-laki yang tidak setuju jika belajar dengan game menjadi menyenangkan dibandingkan dengan siswa perempuan. Hal ini dikarenakan oleh jenis game yang dimainkan. Siswa laki-laki dan siswa perempuan memiliki perbedaan dalam game yang disukai. Siswa perempuan biasanya tidak suka dengan game yang mengandung unsur kekerasan (seperti gamefighting), berbeda dengan siswa laki-laki (Hartmann \& Klimmt, 2006).

\section{Media Game Edukasi meningkatkan Motivasi Belajar Siswa}

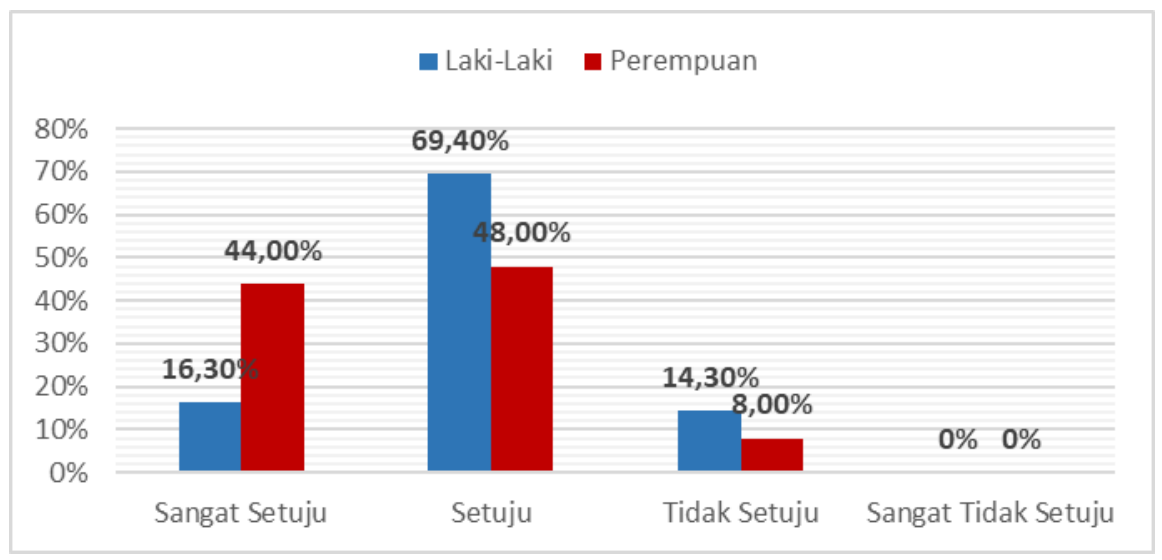

Gambar 2.Tanggapan Siswaberdasarkan Gender pada Pernyataan 2

Salah satu hal terpenting dalam pembelajaran matematika adalah dapat membangun motivasi belajar siswa. Data menunjukkan sebagian besar siswa setuju bahwa game edukasi meningkatkan motivasi belajar matematika. Sama seperti pada data pernyataan 1, lebih banyak siswa laki-laki yang tidak setuju jika belajar dengan game menjadi menyenangkan dibandingkan dengan siswa perempuan. 
Motivasi siswa dapat meningkat karena berbagai unsur yang ada di dalam game. Salah satunya adalah level yang bertingkat di dalam game. Naik level di dalam game membuat siswa merasakan reward atas hasil jerih payah mereka untuk menyelesaikan game. Kompetisi yang dirasakan siswa saat bermain game juga berbeda. Biasanya siswa hanya mengerjakan soal dari buku, LKS, atau soal yang diberikan oleh guru. Soal yang disajikan dalam game merupakan salah satu kompetisi yang dapat meningkatkan motivasi siswa untuk menyelesaikannya.

Wijaya (2009: 11) mengungkapkan bahwa game memiliki daya tarik yang dapat meningkatkan motivasi maupun kepuasan siswa dalam kegiatan pembelajaran. Setyadi (2017: 91) juga menemukan bahwa media pembelajaran game dapat memotivasi siswa untuk berlatih mengerjakan berbagai soal pada mata pelajaran matematika. Dapat dikatakan, bahwa game dapat memotivasi belajar siswa pada pembelajaran matematika.

\section{Misiyang disajikanMedia Game Edukasi Membuat Siswa Memperhatikan Materi}

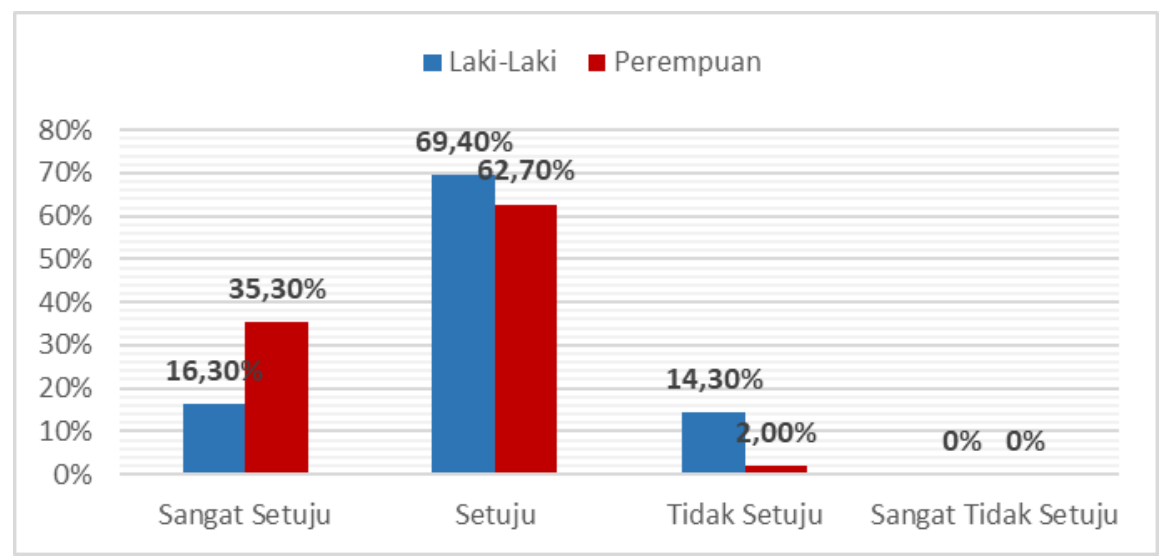

Gambar 3.Tanggapan Siswa berdasarkan Gender pada Pernyataan 3

Hasil pada Gambar 3. sesuai dengan hasil sebelumnya bahwa game dapat membuat pembelajaran menjadi menyenangkan dan siswa termotivasi untuk belajar matematika.Jika siswa sudah belajar dengan perasaan senang dan motivasi tinggi, maka kemungkinan besar siswa juga akan memperhatikan materi yang diajarkan.Perhatian siswa yang besar dapat mempengaruhi kemampuan siswa dalam pembelajaran. Misi yang disajikan pada game dapat membuat siswa memperhatikan materi

Selain misi yang jelas dan mudah dipahami, desain game yang menarik dapat membuat siswa memperhatikan materi yang disajikan media game. Penting bagi guru untuk menyajikan materi dalam game dengan menarik dan runtun, sehingga siswa tertarik untuk memperhatikan materi dan memahaminya. Media game yang mudah digunakan dan dimainkan dapat membuat siswa lebih cepat dalam mengolah informasi (Pramuditya, Noto, \&Purwono, 2018: 177). Game matematika juga memberikan fasilitas kepada guru dan siswa untuk menerapkan pengetahuan mereka dalam 
menyelesaikan masalah matematika (Araya et al., 2011: 8).

\section{Menyelesaikan Misi pada Media Game Edukasimerupakan Hal yang Menantang}

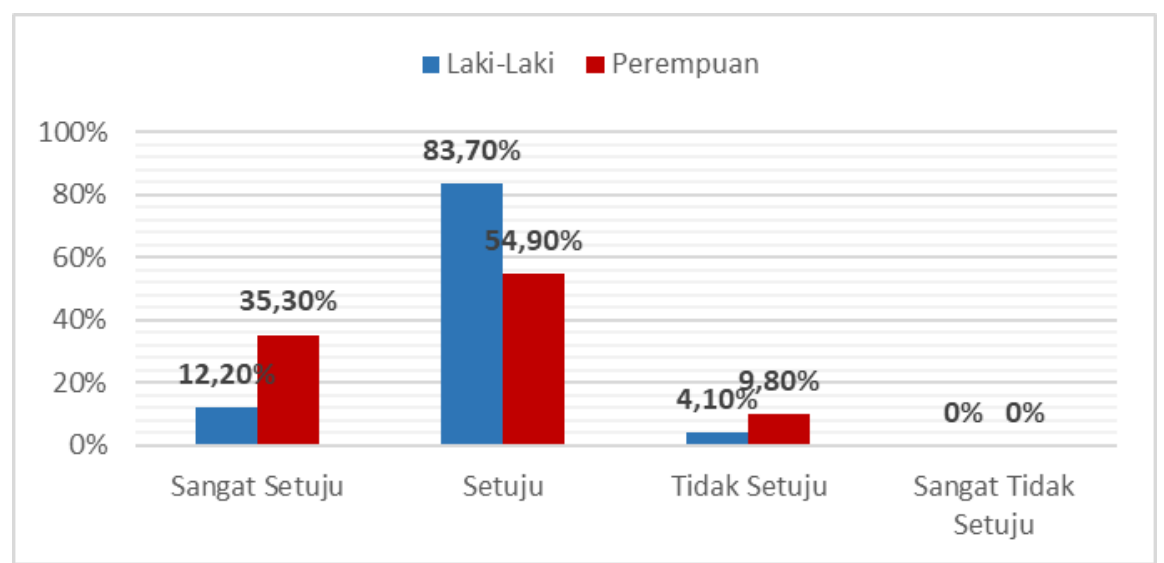

Gambar 4.TanggapanSiswa berdasarkan Gender pada Pernyataan 4

Tantangan dalam game merupakan salah satu komponen yang penting. Berbagai misi yang ada dapat memberikan tantangan lebih kepada siswa. Abdullah dan Yunianta (2018: 441) mengungkapkan bahwa siswa merasa antusias dan menarik jika belajar dengan game, salah satunya karena mengerjakan soal matematika dirasakan sebagai ajang persaingan bagi mereka atau tantangan bagi mereka.

Tantangan juga merupakan salah satu faktor yang membuat belajar dalam game menjadi menyenangkan.Lebih lanjut, Erfaniet al. (2010: 293) mengungkapkan bahwa pemain menikmati permainan walaupun mereka belum sepenuhnya menguasainya. Hal ini menunjukkan bahwa tantangan dalam game diperlukan untuk membuat pembelajaran menjadi menyenangkan.

Data di atas juga menunjukkan bahwa lebih banyak siswa laki-laki yang setuju bahwa misi pada game merupakan hal yang menantang. Selain itu, hasil penelitian mengemukakan bahwa siswa laki-laki lebih banyak menggunakan strategi dengan baik saat bermain game dibandingkan dengan perempuan (Araya et al., 2011: 6). Strategi yang digunakandalam game untuk menyelesaikan misi, dipengaruhi oleh jenis game yang dimainkan siswa.Guru perlu memperhatikan hal ini saat menggunakan game sebagai media belajar.

\section{KESIMPULAN}

Game edukasi matematika merupakan salah satu media yang dapat digunakan untuk memfasilitasi pembelajaran. Baik siswa laki-laki maupun perempuan dapat memanfaatkan media ini. Belajar matematika yang menyenangkan dapat diwujudkan melalui game edukasi. Selain itu, motivasi belajar dan perhatian siswa juga dapat dibangun terhadap pembelajaran. Berbagai misi dalam game 
Game edukasi pada pembelajaran matematika: tanggapan siswa SMP berdasarkan gender. Salsabila, Lu'luilmaknun, 31 Novitasari, Tyaningsih, \& Ardani.

dapat membantu siswa memperhatikan materi dan merasakan tantangan. Hal yang perlu diperhatikan guru dalam penggunaan game edukasi adalah terkait dengan gender siswa. Jenis game maupun tantangan yang ada bisa mempengaruhi respon maupun kinerja siswa berdasarkan gender.

\section{DAFTAR PUSTAKA}

Abdullah, F. S., \&Yunianta, T. N. H. (2018). Pengembangan media pembelajaran matematika trigo fun berbasis game edukasi menggunakan adobe animate pada materi trigonometri. AKSIOMA: Jurnal Program Studi Pendidikan Matematika, 7(3), 434-443.

Araya, R., Jiménez, A., Bahamondez, M., Dartnell, P., Soto-Andrade, J., González, P., \&Calfucura, P. (2011). Strategies used by students on a massively multiplayer online mathematics game. International Conference on Web-Based Learning, 1-10. Springer, Berlin, Heidelberg.

Chan, E. (2008). Girls playing games: the effect of gender stereotypes on video game playing motivation and performance. Meaningful Play.

Decision Lab \& Mobile Marketing Association. (2018). Jumlahgamer di Indonesia capai 100 juta di 2020, (Online),(https://www.tek.id/insight/jumlah-gamer-di-indonesia-capai-100-juta-di-2020b1U7v9c4A), diakses 21 Desember 2019.

Erfani, M., El-Nasr, M. S., Milam, D., Aghabeigi, B., Lameman, B. A., Riecke, B. E., ... \&Mah, S. (2010). The effect of age, gender, and previous gaming experience on game play performance. IFIP Human-Computer Interaction Symposium, 293-296. Springer, Berlin, Heidelberg.

Hartmann, T., \&Klimmt, C. (2006). Gender and computer games: Exploring females' dislikes. Journal of Computer-Mediated Communication, 11(4), 910-931.

Pramesti, G., Aryuna, D. R., Sudjatmiko, P., \&Mardiyana, M. (2014). Pengembangan media game interaktif bilingual berbasis pendidikan karakter dalam pembelajaran matematika di sekolah menengah atas. Infinity Journal, 3(1), 1-17.

Pramuditya, S. A., Noto, M. S., \&Purwono, H. (2018). Desain game edukasiberbasis android pada materilogikamatematika. JNPM (Jurnal Nasional Pendidikan Matematika), 2(2), 165-179.

Setyadi, D. (2017). Pengembangan mobile learning berbasis android sebagai sarana berlatih mengerjakan soal matematika. Satya Widya, 33(2), 87-92.

Siregar, N. R. (2017). Persepsi siswa pada pelajaran matematika: studi pendahuluan pada siswa yang menyenangi game. Prosiding Temu Ilmiah Nasional X Ikatan Psikologi Perkembangan Indonesia, 1 .

Suartama, I. G. A., Suciptawati, N. L. P., \&Asih, N. M. (2019).Identifikasifaktor-faktor yang memengaruhiremajabermain role playing game pada smartphone. E-JurnalMatematika, $8(3)$, 194-198.

Tassell, J. L., Novak, E., \& Wu, M. (2018). Video game play, mathematics, spatial skills, and creativity - a study of the impact on teacher candidates. Creativity and Technology in Mathematics Education, 303-322. Springer, Cham. 
Wijaya, A. (2009). The power of games to learn mathematics: An overview. Pythagoras: Jurnal Pendidikan Matematika, 5(1), 1-12. 